\title{
The Effect of Knowledge Management and Talent Management on Employee Performance
}

\author{
Hana Angelica Daniella Mantow ${ }^{1}$ and B. Medina Nilasari ${ }^{2, *}$ \\ ${ }_{1,2}$ Magister Manajemen, Fakultas Ekonomi dan Bisnis, Universitas Trisakti, Jakarta, Indonesia \\ Email address: \\ angelica.hanna@yahoo.com,medina@trisakti.ac.id
}

\begin{abstract}
Research objective are to see the impact of knowledge management and talent management on employee performance mediated by employee development. The sample of research is 225 employees who work in the field of information technology in the Jakarta area. Data analysis method using Structural Equation Model. The study showed that knowledge management and talent management have an impact on employee performance, the employee development variable is proven to be a mediation between knowledge management and employee performance, but the employee development variable cannot mediate between talent management and employee performance. Companies should provide knowledge management such as providing company web facilities as a place where employees can share their knowledge, and also develop talent management with training and development programs that will improve employee performance.
\end{abstract}

Keywords: Knowledge Management, Talent Management, Employee Performance, Employee Development.

\begin{abstract}
Abstrak: Tujuan penelitian untuk menganalisis pengaruh manajemen pengetahuan dan manajemen talenta terhadap kinerja karyawan melalui pengembangan karyawan. Sampel penelitian adalah 225 karyawan yang bekerja di bidang teknologi informasi di wilayah Jakarta. Metode Analisa data yang digunakan adalah Structural Equation Model. Hasil studi memperlihatkan bahwa manajemen pengetahuan dan manajemen talenta berpengaruh terhadap kinerja karyawan. Dari temuan juga membuktikan pengaruh manajemen talenta terhadap pengembangan karyawan. Selain itu, variabel pengembangan karyawan terbukti menjadi mediasi antara manajemen pengetahuan dan kinerja karyawan, tetapi variabel pengembangan karyawan tidak dapat memediasi antara manajemen talenta dan kinerja karyawan. Perusahaan harus menyediakan manajemen pengetahuan seperti menyediakan fasilitas web perusahaan sebagai tempat karyawan berbagi pengetahuan, dan juga mengembangkan manajemen talenta dengan program pelatihan dan pengembangan yang dapat meningkatkan kinerja karyawan.
\end{abstract}

Kata kunci: Manajemen Pengetahuan, Manajemen Talent, Kinerja Karyawan, Pengembangan Karyawan. 


\section{INTRODUCTION}

The Covid-19 pandemic creates very high uncertainty. This has a severe impact on the condition of the business world. Organizations must make innovative changes in order to survive. Organizations need to be careful in making decisions to make the right strategy, so that businesses can continue to run in the new economic situation in 2022. Technology investment is considered important. Technology investment makes business processes faster, more effective and efficient (Rahajeng, 2021). So companies must prepare their talents to adapt rapid technological changes, especially information technology. Companies need to make how human resource development affects in order to advance the company itself.

Therefore human resources is a very important part in the progress of the company. (Ghalem et al., 2017) explain that performance is an achievement of goals that are more for the company than individual goals with minimal resources used to achieve goals. (Zaim et al., 2018) stated that knowledge management is an important solution in every company to achieve superior employee performance. (Angliawati and Maulyan, 2020) explained that talent management is a technique used by management in companies to manage their talents.

In addition to knowledge management and talent management as a management strategy to develop employee performance, employee development is also one way to improve employee performance. Every company needs to manage its talent and knowledge so that employees can improve their respective performance in doing the assigned tasks.

Companies need to support their employees who are looking for 'something' in themselves for career advancement, and also motivate their employees to create their own knowledge because it will improve their skills and potential, and which can ultimately affect employee performance. So, in this study will examine how talent management and knowledge management affect employee performance and employee development. The scope that will examine are employees with working status in the field of Information Technology.

\section{THEORITICAL REVIEW}

Employee Performance. Acording to (Soe and Aye, 2020) explained that employee performance is considered as all activities carried out by employees involved in fulfilling obligations towards achieving company goals and objectives. According to (Kaleem, 2019), employee performance is usually determined through the work assigned to employees. The performance of the tasks in question such as attendance at work, quality and quantity of work and also timeliness to aspects of employee behavior. (Mensah, 2015) explains that employee performance is an employee's positive contribution to performance within the company. Therefore, employee performance is an activity carried out to obtain the achievement of the abilities and skills of each employee as measured by accuracy standards and also to improve how employees perform in completing the assigned tasks. Employee performance is also a contribution by employees in achieving company goals.

Knowledge Management. According to (Hariadi et al., 2020) knowledge management is a processes of series to create, communicate, and apply corporate knowledge to generate value 
of business and improve learning then performance of employees and organizations alike. Knowledge management is an important solution for every company to achieve superior employee performance, and be able to compete in today's global business environment (Zaim et al., 2018). Knowledge management is a process to access experience, knowledge and expertise that creates new skills, active performance, and also encourages motivation, said (Alyoubi et al., 2018). So it can be concluded that knowledge management is a process of creating knowledge to applying that knowledge in achieving company goals. Knowledge management is also an important tool that prepares companies to successfully enter the digital economy era. The process as well as the knowledge management approach affects job satisfaction and will improve employee performance.

Talent Management. (Hariadi et al., 2020) said, talent management is the process of nurturing, developing, and strengthening employees, also new employees in the company to create talented employees or develop the talent of employees. According to (Ogbu and Dialoke, 2017) talent management also a process of finding talent, developing, utilizing and also maintaining talent by the human resources department within the company. Therefore, talent management is a process carried out by companies to manage their employees to get employees who have talent and can develop them to achieve company goals. The effect of talent management on employee performance shows a positive influence through talent management training which includes talent development, career development and work-life balance on employee performance.

Employee Development. According (Jayathilake et al., 2021) employee development can improvise knowledge and skills that are important for future competition. (Glazer et al., 2019) concluded that employee development can increase employee commitment to the company which can improve employee retention. According to (Awasthi and Kumar, 2016), the development of employee can create professional personal growth and the company can help employees in build leadership strategically, work culture effectively, performance responsibility, and communication relationships effectively. Therefore, employee development is a company process activity in developing employee skills and abilities so that they can find out what abilities they have, and so that the company can assign positions and tasks to employees according to the abilities of each employee.

The conceptual framework shown in Figure 1: 


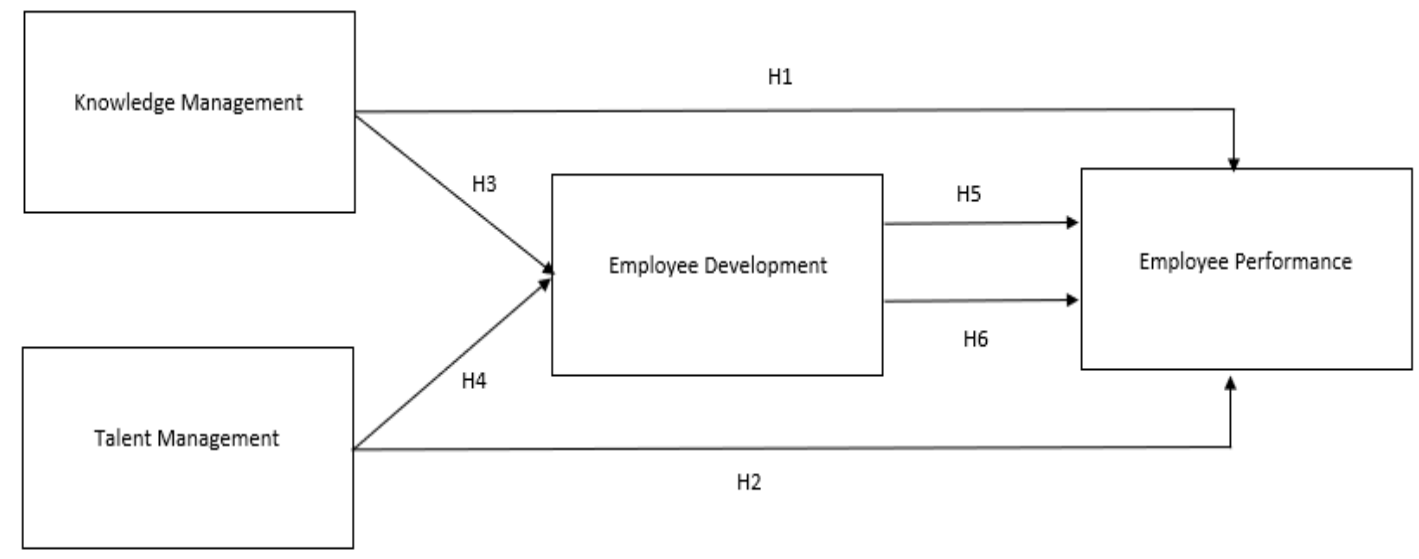

Figure 1. Research Model

Sources: (Hariadi et al., 2020) and (Hasbi, 2020)

Hypothesis. Knowledge management is the process of nature identification of intelligence and creating a culture and infrastructure that encourages collaboration. Knowledge management can develop skills and also motivate employees to work so that they can motivate progress in the performance of each individual and company. Employee performance will get high performance results if it can be driven by knowledge. Based on the research of (Mahmudi and Monavvar, 2016), that knowledge management can affect the progress of employee performance, it can be concluded that the temporary hypothesis that became the formulation of the research above, namely:

H1: knowledge management has an effect on employee performance.

Talent management is an activity that not only recruits, trains and places employees in the right jobs and at the right time, but talent management is a training on how to rotate employees' jobs. This can make the company renew the skills of each employee which affects the achievement of high employee performance. Based on research according to (Kaleem, 2019), talent management influence employee performance positively, it can be concluded that the provisional hypothesis that became the formulation of the research above, namely:

H2: talent management has an effect on employee performance.

Management of knowledge currently make a major effect on employee performance. A knowledge management process that is expanded with work experience and knowledge can improve the quality of employees in carrying out assigned tasks effectively if employees carry out a training process that will continue to experience a continuous development process. To create good employee development in terms of training and education, employees need to improve their knowledge management. Based on (Hasbi, 2020) research, stating that knowledge management will not have an impact on employee performance without going through employee development, it is indirectly explained that 
knowledge management has an influence on employee development, so the temporary hypothesis is the formulation of the research above, namely:

H3: knowledge management has an effect on employee development.

Talent management supports development as well as fundamental growth within the company. This makes employees motivated and can also increase the level of development in the company. Based on research by (Fajčíková et al., 2016) states that applying talent management has a positive effect on individual development, it can be concluded that the provisional hypothesis that is the formulation of the research above, namely:

H4: talent management has an effect on employee development.

Knowledge management is one of the parts that is currently well known for developing employee performance in the company. However, knowledge management will not affect the increase in employee performance without going through an employee development process on the basis of training to sharpen IT skills which will create quality and competitive employees. Based on (Hasbi, 2020) research, stating that knowledge management will not have an impact on employee performance without going through employee development, it can be concluded that the provisional hypothesis that is the formulation of the research above, namely:

H5: knowledge management has an effect on employee performance mediated by employee development.

Talent management is a stage carried out by companies to manage their talents to create competitiveness with other companies. Based on research by (Angliawati and Maulyan, 2020) which states that talent management has an effect on the development of human resources in the company and also through (Fajčíková et al., 2016) which states that implementing talent management has a positive effect on individual development. Employee performance directly affects the success or failure of the company. So it is necessary for companies to invest a lot of funds to develop their employees. Based on the research of (Urbancová and Vnoučková, 2018) which states that employee development significantly affects commitment, loyalty, and employee performance, it can be concluded that the provisional hypothesis that became the formulation of the research above, namely:

H6: talent management has an effect on employee performance mediated by employee development.

\section{METHODS}

The type of research used is hypothesis testing. Hypothesis testing in this study is a causal hypothesis, that is a provisional assumption in the formulation of the problem that questions whether there is an influence of the alleged factor on the response variable. This research tested impact of knowledge management, talent management as independent 
variables on employee performance as the dependent variable through employee development as an intervening variable. The variables, dimensions and indicators of this research in table 1 below:

Table 1. Variables, Dimensions, and Indicators

\begin{tabular}{|c|c|c|c|}
\hline Variable & Dimension & Indicators & Sources \\
\hline \multirow[t]{12}{*}{$\begin{array}{l}\text { Knowledge } \\
\text { Management }\end{array}$} & \multirow{3}{*}{$\begin{array}{l}\text { Knowledge } \\
\text { Generation }\end{array}$} & $\begin{array}{l}\text { My company motivates me to innovate in generating new } \\
\text { knowledge. }\end{array}$ & \multirow[t]{12}{*}{$\begin{array}{l}\text { (Obaidat and } \\
\text { Otair, 2018) }\end{array}$} \\
\hline & & $\begin{array}{l}\text { My company provides mechanisms and means to give me the } \\
\text { opportunity to acquire existing knowledge. }\end{array}$ & \\
\hline & & My company makes sure to oversee the creation of knowledge. & \\
\hline & \multirow{3}{*}{$\begin{array}{l}\text { Knowledge } \\
\text { Storage }\end{array}$} & $\begin{array}{l}\text { My company has flexible mechanisms and tools for storing } \\
\text { knowledge available. }\end{array}$ & \\
\hline & & $\begin{array}{l}\text { My company protects hardcopy records and documents to store } \\
\text { data. }\end{array}$ & \\
\hline & & $\begin{array}{l}\text { My company provides modern technology facilities and } \\
\text { information systems to store knowledge. }\end{array}$ & \\
\hline & \multirow{3}{*}{$\begin{array}{l}\text { Knowledge } \\
\text { Sharing }\end{array}$} & $\begin{array}{l}\text { My company provides modern technological means in } \\
\text { transmitting knowledge to fellow employees }\end{array}$ & \\
\hline & & $\begin{array}{l}\text { My company provides various publications and documents to } \\
\text { disseminate knowledge regularly to employees. }\end{array}$ & \\
\hline & & $\begin{array}{l}\text { My company is trying to instill a culture of sharing knowledge } \\
\text { among its employees. }\end{array}$ & \\
\hline & \multirow{3}{*}{$\begin{array}{l}\text { Knowledge } \\
\text { Application }\end{array}$} & $\begin{array}{l}\text { Relevant knowledge is always available to employees when } \\
\text { needed at a certain time. }\end{array}$ & \\
\hline & & $\begin{array}{l}\text { My company provides the necessary facilities and tools to apply } \\
\text { existing knowledge }\end{array}$ & \\
\hline & & $\begin{array}{l}\text { My company provides a suitable environment for employees to } \\
\text { exchange knowledge }\end{array}$ & \\
\hline \multirow[t]{12}{*}{$\begin{array}{l}\text { Talent } \\
\text { Management }\end{array}$} & \multirow{3}{*}{$\begin{array}{l}\text { Talent } \\
\text { Acquisition }\end{array}$} & $\begin{array}{l}\text { My company is fair and transparent about talent acquisition } \\
\text { policies and processes. }\end{array}$ & \multirow[t]{12}{*}{ (Kaleem, 2019) } \\
\hline & & $\begin{array}{l}\text { The talent acquisition process and schedule is shared with the } \\
\text { candidates. }\end{array}$ & \\
\hline & & $\begin{array}{l}\text { After acquiring talent, the orientation process between } \\
\text { employees is easy and friendly. }\end{array}$ & \\
\hline & \multirow{3}{*}{$\begin{array}{l}\text { Talent } \\
\text { Development }\end{array}$} & My company offers systematic training to its employees. & \\
\hline & & My company raises talent. & \\
\hline & & My company implements activities in staff development. & \\
\hline & \multirow{3}{*}{$\begin{array}{l}\text { Talent } \\
\text { Retention }\end{array}$} & $\begin{array}{l}\text { My company evaluates and communicates job performance to } \\
\text { its employees. }\end{array}$ & \\
\hline & & $\begin{array}{l}\text { Performance appraisal has a positive impact on employee } \\
\text { performance. }\end{array}$ & \\
\hline & & $\begin{array}{l}\text { My company believes that every position requires talented } \\
\text { employees. }\end{array}$ & \\
\hline & \multirow{3}{*}{$\begin{array}{l}\text { Talent } \\
\text { Management }\end{array}$} & $\begin{array}{l}\text { My company focuses on the promotion and development that } \\
\text { its employees need. }\end{array}$ & \\
\hline & & $\begin{array}{l}\text { My company has a strong development program that will be } \\
\text { influential in retaining staff. }\end{array}$ & \\
\hline & & $\begin{array}{l}\text { There are initiatives in training to improve employee } \\
\text { performance. }\end{array}$ & \\
\hline \multirow[t]{2}{*}{$\begin{array}{l}\text { Employee } \\
\text { Development }\end{array}$} & \multirow{2}{*}{$\begin{array}{l}\text { Training and } \\
\text { Skill } \\
\text { Development }\end{array}$} & $\begin{array}{l}\text { Extensive training program is provided for the employees of this } \\
\text { company. }\end{array}$ & \multirow{2}{*}{$\begin{array}{l}\text { (Jangbahadur } \\
\text { and Sharma, } \\
\text { 2018) }\end{array}$} \\
\hline & & Employees usually do training every few years. & \\
\hline
\end{tabular}




\begin{tabular}{|c|c|c|c|}
\hline & & $\begin{array}{l}\text { Training programs are offered to increase the level of } \\
\text { employment in the company. }\end{array}$ & \\
\hline & \multirow{3}{*}{$\begin{array}{l}\text { Leadership } \\
\text { Development }\end{array}$} & My boss helps me find answers to the problems I ask him & \\
\hline & & My boss supports my efforts to gain new knowledge and skills & \\
\hline & & $\begin{array}{l}\text { My boss uses analogies, scenarios and examples to enable me } \\
\text { to learn. }\end{array}$ & \\
\hline & \multirow{3}{*}{$\begin{array}{l}\text { Self- } \\
\text { Development }\end{array}$} & The job allowed me to make many decisions myself. & \\
\hline & & Job duties are assigned to promote personal development. & \\
\hline & & $\begin{array}{l}\text { The job gives me the opportunity to use my personal initiative } \\
\text { or my decisions in doing the work. }\end{array}$ & \\
\hline & \multirow{3}{*}{$\begin{array}{l}\text { Career } \\
\text { Development }\end{array}$} & The training program is offered in my company. & \\
\hline & & $\begin{array}{l}\text { I can easily consult with my supervisor regarding my career } \\
\text { development. }\end{array}$ & \\
\hline & & I develop my skills to achieve my career goals. & \\
\hline \multirow{9}{*}{$\begin{array}{l}\text { Employee } \\
\text { Performance }\end{array}$} & \multirow{3}{*}{$\begin{array}{l}\text { Task } \\
\text { Performance }\end{array}$} & I maintain high performance standards. & \multirow{9}{*}{$\begin{array}{l}\text { (Pradhan and } \\
\text { Jena, 2017) }\end{array}$} \\
\hline & & I am very passionate about my work. & \\
\hline & & I completing assignments on time. & \\
\hline & \multirow{3}{*}{$\begin{array}{l}\text { Adaptive } \\
\text { Performance }\end{array}$} & I can manage to change my job whenever the situation demands. & \\
\hline & & I handle team work effectively in the face of change. & \\
\hline & & I am comfortable with the flexible work. & \\
\hline & \multirow{3}{*}{$\begin{array}{l}\text { Contextual } \\
\text { Performance }\end{array}$} & I usually help my co-workers when asked or needed & \\
\hline & & $\begin{array}{l}\text { I am participate in group discussions and work meetings } \\
\text { actively. }\end{array}$ & \\
\hline & & I praise co-workers for a job that done well. & \\
\hline
\end{tabular}

This study used primary data. Data collection techniques with questionnaires. Questionnaires are distributed online using Google Forms. The questionnaire used a Likert scale of 1-5 where a scale of 1 is strongly disagree, 2 means disagree, 3 means quite agree, 4 means agree, and 5 means strongly agree.

The unit of analysis that will be addressed is the individual, namely every employee who has an information technology background. This study using simple random sampling. Sampling is done randomly without looking at the strata contained in the population. To determine the number of samples based on Hair's theory that the minimum number of samples is $100-400$ or the number of indicators plus 5 . Based on the number of indicators plus 5 is 225 samples.

The statistical method that will be taken using the Structural Equation Model (SEM) method, SEM is a model that has a combination of factor analysis, multiple regression and correlation. To perform data processing with SEM, used the statistical software, namely Smart PLS. The following is a display of the SEM model related to this research which is shown in Figure 2. 


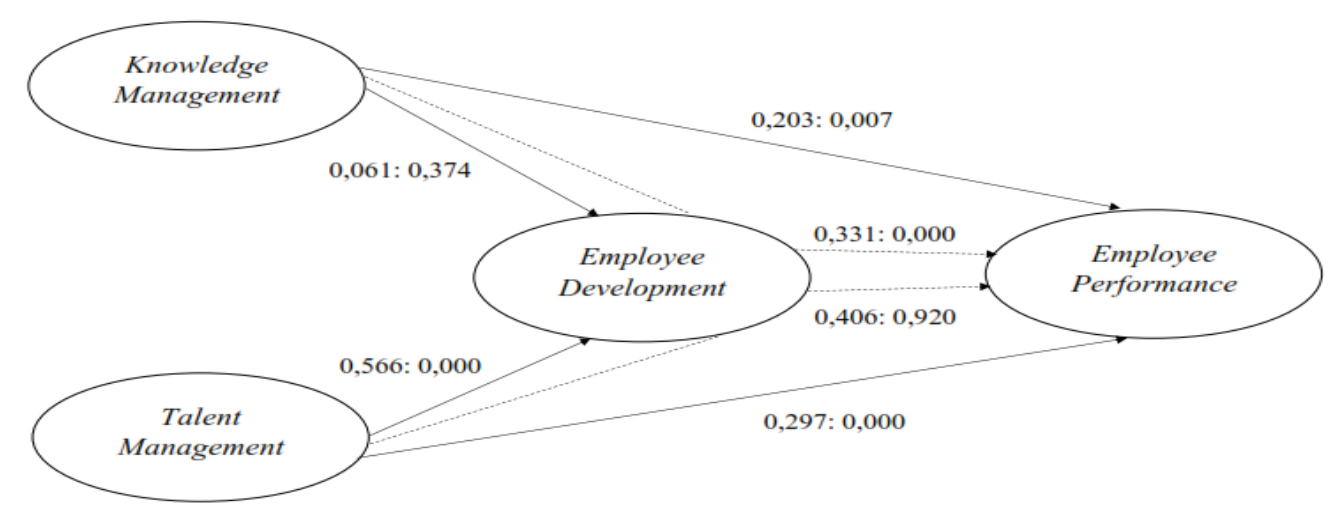

Figure 2. SEM Model

Source: Results of AMOS (2021)

\section{RESULTS}

To measure the accuracy of the questionnaire indicators, the validity test is used and will get results whether the questions given are valid or not.

Table 2. Validitity Test Results of Knowledge Management

\begin{tabular}{l|l|l}
\hline Knowledge Management & Loading Factor & Decision \\
\hline KM1 & 0.673 & Valid \\
\hline KM2 & 0.724 & Valid \\
\hline KM3 & 0.713 & Valid \\
\hline KM4 & 0.803 & Valid \\
\hline KM5 & 0.748 & Valid \\
\hline KM6 & 0.795 & Valid \\
\hline KM8 & 0.784 & Valid \\
\hline KM9 & 0.778 & Valid \\
\hline KM10 & 0.789 & Valid \\
\hline KM11 & 0.699 & Valid \\
\hline KM12 & 0.765 & Valid \\
\hline
\end{tabular}

Source: Output SPSS (2021)

In table above, the results of the validity test of knowledge management, obtained a factor loading value of 0.35 , which means each statement item used to measure knowledge management is correct. 
Table 3. Validitity Test Results of Talent Management

\begin{tabular}{l|l|l}
\hline Talent Management & LoadingFactor & Decision \\
\hline TM1 & 0.670 & Valid \\
\hline TM2 & 0.731 & Valid \\
\hline TM3 & 0.728 & Valid \\
\hline TM4 & 0.522 & Valid \\
\hline TM5 & 0.803 & Valid \\
\hline TM6 & 0.694 & Valid \\
\hline TM8 & 0.726 & Valid \\
\hline TM9 & 0.616 & Valid \\
\hline TM10 & 0.726 & Valid \\
\hline TM11 & 0.820 & Valid \\
\hline TM12 & 0.797 & Valid \\
\hline
\end{tabular}

Source: Output SPSS (2021)

In table above, the results of the validity test of talent management, obtained a factor loading value of 0.35 , which means each statement item used to measure talent management is correct.

Table 4. Validitity Test Results of Employee Development

\begin{tabular}{l|l|l}
\hline Employee Development & Loading Factor & Decision \\
\hline ED1 & 0.687 & Valid \\
\hline ED2 & 0.621 & Valid \\
\hline ED3 & 0.695 & Valid \\
\hline ED4 & 0.736 & Valid \\
\hline ED5 & 0.772 & Valid \\
\hline ED6 & 0.742 & Valid \\
\hline ED7 & 0.793 & Valid \\
\hline ED8 & 0.758 & Valid \\
\hline ED9 & 0.783 & Valid \\
\hline ED10 & 0.810 & Valid \\
\hline ED12 & 0.780 & Valid \\
\hline SDure: & 0.660 & Valid \\
\hline
\end{tabular}

Source: Output SPSS (2021)

On the results of the validity test of employee development, obtained a factor loading value of 0.35 , which means each statement item used to measure employee development is correct. 
Table 5. Validitity Test Results of Employee Performance

\begin{tabular}{l|c|c}
\hline $\begin{array}{l}\text { Statements of } \\
\text { Employee Performance }\end{array}$ & $\begin{array}{c}\text { Loading } \\
\text { Factor }\end{array}$ & Decision \\
\hline EP1 & 0.730 & Valid \\
\hline EP2 & 0.804 & Valid \\
\hline EP3 & 0.845 & Valid \\
\hline EP4 & 0.784 & Valid \\
\hline EP5 & 0.844 & Valid \\
\hline EP6 & 0.740 & Valid \\
\hline EP7 & 0.851 & Valid \\
\hline EP8 & 0.853 & Valid \\
\hline EP9 & 0.856 & Valid \\
\hline
\end{tabular}

Source: Output SPSS (2021)

On the results of the validity test of the employee performance, obtained a factor loading value of 0.35 , which means each statement item used to measure employee performance is correct.

Table 6. Reliability Test Results

\begin{tabular}{c|l|l|l|l}
\hline No & \multicolumn{1}{|c|}{ Variables } & $\begin{array}{c}\text { Numbers of } \\
\text { Statements }\end{array}$ & $\begin{array}{c}\text { Cronbach's } \\
\text { Alpha }\end{array}$ & \multicolumn{1}{|c}{ Decision } \\
\hline 1 & Knowledge Management & 12 & 0.930 & Reliable \\
\hline 2 & Talent Management & 12 & 0.915 & Reliable \\
\hline 3 & Employee Development & 12 & 0.922 & Reliable \\
\hline 4 & Employee Performance & 9 & 0.935 & Reliable \\
\hline
\end{tabular}

Source: Output SPSS (2021)

In table above, the value of Cronbach's alpha as a result of the reliability test of the existing instruments on the variables of knowledge management, talent management, employee development and employee performance. All indicators in each variable have a Cronbach's alpha value greater than 0.6, means all indicators used in the research variables are reliable. The goodness of fit model was tested before testing the hypothesis, and the results are:

Table 7. Goodness of Fit Test Results

\begin{tabular}{l|l|l|l|l}
\hline Type & Measurement & Value & Suggested acceptance limit & Decision \\
\hline $\begin{array}{l}\text { Absolute } \\
\text { measures }\end{array}$ & $p$ & 0,000 & $\geq 0,05$ & Poor Fit \\
\cline { 2 - 5 } & ECVI & 10,168 & $\begin{array}{l}\text { Closer to Saturated value than } \\
\text { independent }\end{array}$ & Goodness Fit \\
\cline { 2 - 5 } $\begin{array}{l}\text { Incremental fit } \\
\text { measures }\end{array}$ & RMSEA & 0,075 & $\leq 0,1$ & Goodness of Fit \\
\cline { 2 - 5 } & NFI & 0,829 & $\geq 0.90$ or close to 1 & Marginal Fit \\
\cline { 2 - 5 } & TLI & 0,732 & $\geq 0.90$ or close to 1 & Poor Fit \\
\cline { 2 - 5 } & CFI & 0,818 & $\geq 0.90$ or close to 1 & Marginal Fit \\
\hline
\end{tabular}




\begin{tabular}{l|l|l|l|l}
\hline & RFI & 0,717 & $\geq 0.90$ or close to 1 & Poor Fit \\
\hline $\begin{array}{l}\text { Parsimonius fit } \\
\text { measure }\end{array}$ & CMIN/DF & 2,286 & Lower limit 1, upper limit 5 & Goodness of Fit \\
\cline { 2 - 5 } & AIC & 2338,610 & $\begin{array}{l}\text { Closer to Saturated value than } \\
\text { independent }\end{array}$ & Goodness of Fit \\
\hline
\end{tabular}

Source: Output AMOS (2021)

Based on table above concluded that overall model used in this study resulted in a good level of model suitability and good acceptance. The following is a table of hypothesis test results:

Table 8. Hypothesis Testing Results 1-4

\begin{tabular}{|c|c|c|c|}
\hline Hypothesis & Estimate & $p$-value & Decision \\
\hline $\begin{array}{l}\text { H1: Knowledge management affects employee } \\
\text { performance }\end{array}$ & 0,203 & 0,007 & H1 Supported \\
\hline 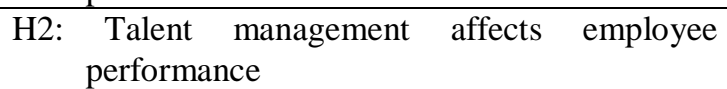 & 0,297 & 0,000 & H2 Supported \\
\hline $\begin{array}{l}\text { H3: Knowledge management affects employee } \\
\text { development }\end{array}$ & 0.061 & 0,374 & $\begin{array}{l}\text { H3 } \\
\text { Not Supported }\end{array}$ \\
\hline $\begin{array}{l}\text { H4: } \begin{array}{c}\text { Talent management affects employee } \\
\text { development }\end{array}\end{array}$ & 0,566 & 0,000 & H4 Supported \\
\hline
\end{tabular}

Source: Output AMOS (2021)

The results of the first hypothesis test have an estimate value of 0.203 with a p-value of 0.0070 .05 , which means that the hypothesis is supported (Ho is rejected). Therefore, it can be concluded that knowledge management has a significant influence on employee performance. This means that the application of knowledge management needs to be applied by the company because it can influence and improve the performance of employees which will create opportunities to achieve company goals. Knowledge that is obtained and created and managed properly can be useful for employees to carry out their duties, so that employee performance at work can improve better.

The results of the second hypothesis test have an estimate value of 0.297 with a $p$ value of 0.000 0.05, which means that the hypothesis is supported (Ho is rejected). Therefore, it can be concluded that talent management has a significant influence on employee performance. This means that the application of talent management in terms of learning, development training requires identification, training and also development programs that will improve employee performance. If employees can manage their skills, this can make it easier for employees to complete the assigned tasks.

The results of the third hypothesis test have an estimate value of 0.061 with a p-value of 0.374 greater than 0.05 , which means that the hypothesis is not supported ( $\mathrm{Ha}$ is rejected). Therefore, it can be concluded that knowledge management has no significant effect on employee development. That is, if the company applies knowledge management within the company, this will not have a direct effect on employee development in the company. Knowledge management that is developed will result in the knowledge being not original from the creator, which can result in the knowledge having a different meaning, this will have an impact on the employees who get the knowledge. 
The results of the fourth hypothesis test have an estimate value of 0.566 with a $p$ value of 0.05 , which means that the hypothesis is supported (Ho is rejected). Therefore, it can be concluded that talent management has a significant influence on employee development. Thus, the implementation of talent management implemented by companies that include training programs, training, seminars, or webinars can improve how employees develop in carrying out their duties individually and in teams. This can make employees to improvise how employees work on the given task.

Table 9. Hypothesis Testing Results 5

\begin{tabular}{l|l|l|l}
\hline Model & Estimate & P-value & Decision \\
\hline Model 1 (Direct) & & & \\
\hline Knowledge management affects employee performance & 0,409 & 0,000 & Conditions fulfilled (c) \\
\hline Model 2 (Indirect) & & & \\
\hline Knowledge management affects employee development & 0,449 & 0,000 & Conditions fulfilled (a) \\
\hline Employee development affects employee performance & 0,169 & 0,019 & Conditions fulfilled (b) \\
\hline Knowledge management affects employee performance & 0,331 & 0,000 & Conditions fulfilled (c) \\
\hline Source: Output AMOS (2021)
\end{tabular}

The results of testing the intervening variable on the fifth hypothesis that in model one there is an influence of knowledge management on employee performance ( $\mathrm{p}$-value = 0.000 ) and remains significant in model two where ( $\mathrm{p}$-value is 0.000 ), and the first condition is that there is an influence of knowledge management on employee development ( $\mathrm{p}$-value is 0.000 ), and the last condition has the effect of employee development on employee performance ( $\mathrm{p}$-value is 0.019 ). The results of the hypothesis test indicate that knowledge management affects employee performance through employee development. Thus, employee development is the right variable to mediate the influence of knowledge management on employee performance. Thus, it can be concluded that the knowledge management exchange process is not easy in improving employee performance if it is not through the process of employee development that has been described previously hypothesized. Human resource development carried out is such as training and formal education.

Table 10. Hypothesis Testing Results 6

\begin{tabular}{l|l|l|l}
\hline \multicolumn{1}{c|}{ Model } & Estimate & P-value & \multicolumn{1}{c}{ Decision } \\
\hline Model 1 (Direct) & & & \\
\hline Talent management affects employee performance & 0,411 & 0,000 & Conditions fulfilled (c) \\
\hline Model 2 (Indirect) & & & \\
\hline Talent management affects employee development & 0,599 & 0,000 & Conditions fulfilled (a) \\
\hline Employee development affects employee performance & 0,009 & 0,920 & Conditions not fulfilled (b) \\
\hline Talent management affects employee performance & 0406 & 0,000 & Conditions fulfilled (c) \\
\hline \multicolumn{2}{l}{}
\end{tabular}

The results of testing the sixth hypothesis intervening variable that in model one there is an influence of talent management on employee performance ( $p$-value is 0.000$)$ and remains significant in model two ( $\mathrm{p}$-value is 0.000 ), and the first condition is that there is 
an influence of talent management on employee development (p-value is 0.000), while the last condition where employee development affects employee performance ( $\mathrm{p}$-value is 0.920) is not fulfilled in model two. The results of the hypothesis test show that talent management does not affect employee performance through employee development. Thus, employee development is an inappropriate variable to mediate the influence of talent management on employee performance. In this case, it can be concluded that indirectly employee development cannot be a mediation for talent management on employee performance, and it can also be stated that talent management can automatically affect employee performance without having to go through employee development.

\section{DISCUSSION}

The findings of this study are: there is a positive influence of knowledge management on employee performance, meaning that the increasing knowledge management in the company will increase the performance of its employees: there is a positive influence of talent management on employee performance, meaning that the more talent management in the company increases, the performance of its employees will increase; there is no influence of knowledge management on employee development, meaning that employee performance increases not because it is influenced by increased knowledge management; there is a positive influence of talent management on employee development, meaning that if talent management increases, employee development will increase; there is a positive influence of knowledge management on employee performance mediated by employee development, meaning that employee development strengthens the influence of knowledge management on employee performance; there is no influence of talent management on employee performance mediated by employee development, meaning that employee development cannot mediate the influence of talent management on employee performance.

The study show that knowledge management is very much needed for employees who work in the field of information technology, because the development of technology creates knowledge that will continue to grow and need to be managed and stored, useful for employees in carrying out their duties. The results of the study also show that talent management is very much needed for employees who work in the field of information technology, because even though employees can balance their skills against current technological advances, it will not survive if no one manages. Meanwhile, knowledge management is proven to have no effect on employee development, meaning that having or not knowledge management in the company will not affect employee development for the company. This shows that the application of knowledge management has no effect on employee development which states that the knowledge that is owned or created does not need to be developed but needs to be stored and shared with other employees, so that the knowledge obtained will be useful for employees to carry out their duties.

Talent management has a direct effect on employee development. The application of talent management has an influence on employee development so that the talent that is owned or found needs to be developed in order to improve employee performance in the company. Employee development is proven to be the right variable to mediate in the influence of knowledge management on employee performance. The application of knowledge management if developed based on employee work experience and knowledge 
of information technology can improve employee performance in terms of quality, quantity, and timeliness in carrying out the assigned tasks. Likewise, the work functions of each department will run effectively and fully independently if it goes through a related training process and continues to produce a sustainable development process. Meanwhile, employee development is not the right variable to mediate in the influence of talent management on employee performance. So in this case, there is no direct research on employee development as an intermediary for the relationship between knowledge management and employee performance. In this study, it can be seen that to improve employee performance, there is no need for employee development. Because employee development on the talents they have, has no relation to increasing employee performance.

The managerial implications that can be input for managers are as follows: 1). managers can begin to consider various ways to implement talent management, such as increasing training programs to improve employee skills, and knowledge management activities such as preparing facilities for employees to apply their knowledge, as well as creating employee development programs to prepare employees in the future; 2 ). managers need to create training programs that can be held at least once a year to improve talent management for employees, and also provide facilities such as websites that can be used by employees to store and share their knowledge.

\section{CONCLUSION}

Based on findings of research, it can be concluded that there is an influence of knowledge management on employee performance, and influence of talent management on employee performance. But no influence of knowledge management on employee development, meanwhile talent management influence on employee development. Knowledge management will effect employee performance if mediated by employee development. But employee development can't be mediated the effect of talent management on employee performance.

Suggestions further research to conduct research on the direct influence of employee development on employee performance, which was not carried out in this study. Then can also add employee loyalty variables as in the research conducted by Urbancová and Vnoučková, (2018) which states that employee development significantly affects commitment, loyalty and employee performance.

\section{REFERRENCE}

Alyoubi, B., Hoque, M. R., Alharbi, I., Alyoubi, A., and Almazmomi, N. (2018). Impact of Knowledge Management on Employee Work Performance: Evidence from Saudi Arabia. In The International Technology Management Review (Vol. 7, Issue 1).

Angliawati, R. Y., dan Maulyan, F. F. (2020). Peran Talent Management dalam Pembangunan SDM yang Unggul. In Jurnal Sain Manajemen (Vol. 2, Issue 2). http://ejurnal.ars.ac.id/index.php/jsm/index.

Awasthi, S., and Kumar, S. (2016). Need for Employee Development in Employee Performance: A Present Scenario Educonomics of Human Capital Investment View project. https://www.researchgate.net/publication/316664674. 
Fajčíková, A., Fejfarová, M., and Urbancová, H. (2016). Employee development by talent management implementation Development of agricultural enterprises in the knowledge-based economy View project. https://www.researchgate.net/publication/316136586.

Ghalem, Â., Okar, C., Chroqui, R., and Alami, S.(2017). Performance:Aconcept to define! La performance: Unconcept à definer!Techniques. 1. https://doi.org/10.13140/RG.2.2.24800.28165.

Glazer, S., Mahoney, A. C., and Randall, Y. (2019). Employee development's role in organizational commitment: a preliminary investigation comparing generation $\mathrm{X}$ and millennial employees. Industrial and Commercial Training, 51(1), 1-12. https://doi.org/10.1108/ICT-07-2018-0061.

Hariadi, A., Muhammad, D. P., Muhammad, N., Putra, R. (2020). Effect Of Talent Management And Knowledge Man-Agement On Company Reputation With Employee Per-Formance As An Intervening Variable: Case Study Of Employees At PT TASPEN (PERSERO). In The International Journal of Organizational Innovation (Vol. 13, Issue 2).

Hasbi, A. (2020). Pengaruh Knowledge Management terhadap Pengembangan Sumber Daya Manusia dan Kinerja Karyawan Perhotelan di Sulawesi Selatan. Jurnal Kawistara, 10(2), 199. https://doi.org/10.22146/kawistara.56756.

Jangbahadur, U., and Sharma, V. (2018). Measuring Employee Development. Global Business Review, 19(2), 455-476. https://doi.org/10.1177/0972150917713548.

Jayathilake, H. D., Daud, D., Eaw, H. C., and Annuar, N. (2021). Employee development and retention of Generation-Z employees in the post-COVID-19 workplace: a conceptual framework. Benchmarking, 28(7), 2343-2364. https://doi.org/10.1108/BIJ-06-2020-0311.

Kaleem, M. (2019). The Influence of Talent Management on Performance of Employee in Public Sector Institutions of the UAE. Public Administration Research, 8(2), 8. https://doi.org/10.5539/par.v8n2p8.

Mahmudi, R. K., and Monavvar, M. S. (2016). Effect Of Knowledge Management On Employees' Performance Improvement (Vol. 7). www.iioab.org.

Mensah, J. K. (2015). A "coalesced framework" of talent management and employee performance: For further research and practice. International Journal of Productivity and Performance Management, 64(4), 544-566. https://doi.org/10.1108/IJPPM-072014-0100.

Obaidat, H., and Otair, M. A. (2018). The Impact of Knowledge Management on the Function of Employee Performance Appraisals in Industrial Companies - Case Study. International Journal of Managing Information Technology, 10(4), 35-52. https://doi.org/10.5121/ijmit.2018.10403.

Ogbu, E. F., and Dialoke, I. (2017). TALENT MANAGEMENT AND WORKERS' EFFECTIVENESS OF SELECTED HOTELS IN RIVERS STATE. http://www.publishingindia.com.

Pradhan, R. K., \& Jena, L. K. (2017). Employee Performance at Workplace: Conceptual Model and Empirical Validation. Business Perspectives and Research, 5(1), 69-85. https://doi.org/10.1177/2278533716671630.

Rahajeng. (2021). Babak Baru Dunia Usaha Pasca Pandemi Covid-19. 
Soe, K. N. N., and Aye, A. C. (2020). The Mediating Role of Job Satisfaction on The Relationship between Knowledge Management Practices and Employee Work Performance: The Private Banking Case in Myanmar. In TNI Journal of Business Administration and Languages (Vol. 8, Issue 2).

Urbancová, H., and Vnoučková, L. (2018). Impact of employee development in agricultural companies on commitment, loyalty and performance. Acta Universitatis Agriculturae et Silviculturae Mendelianae Brunensis, 66(3), 803-811. https://doi.org/10.11118/actaun201866030803.

Zaim, H., Keceli, Y., Jaradat, A., and Kastrati, S. (2018). The effects of knowledge management processes on human resource management: Mediating role of knowledge utilization. Journal of Science and Technology Policy Management, 9(3), 310-328. https://doi.org/10.1108/JSTPM-02-2018-0011. 